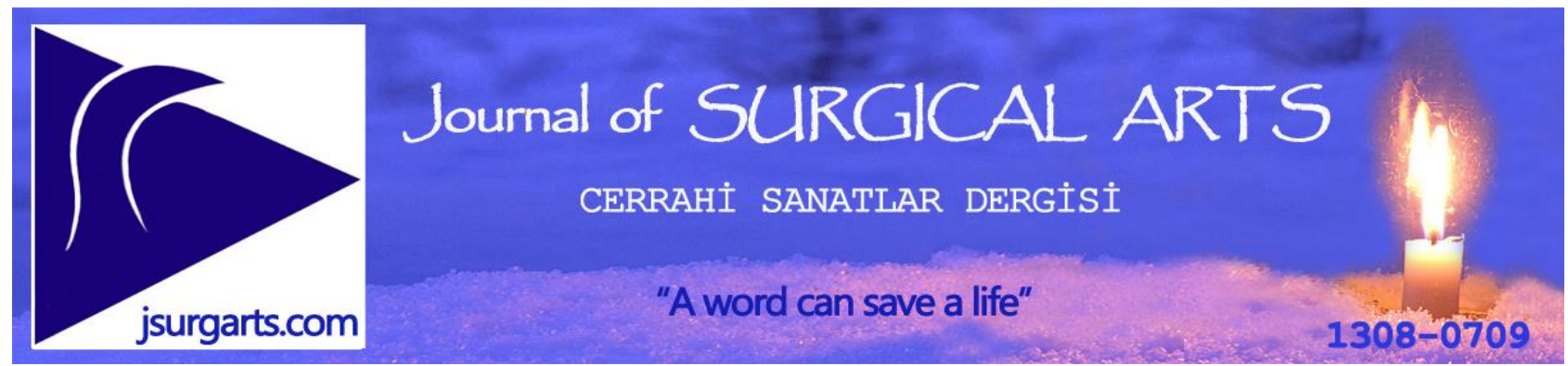

Case report

\title{
Giant left atrial myxoma presenting as cerebral embolism
}

\section{Serebral embolizm ile gelen dev sol atriyal miksoma olgusu}

\author{
Funda Tor Ocak iD, Muhittin Zafer Samsa \\ Adana City Education and Research Hospital, Department of Cardiovascular Surgery, Adana, Turkey \\ Address: Dr. Funda Tor Ocak, fundatorocak@gmail.com \\ How to cite: Ocak FT, Samsa MZ. Giant left atrial myxoma presenting as cerebral embolism. J Surg Arts \\ 2021;14(2):93-96. DOI: http://dx.doi.org/10.14717/jsurgarts-210209
}

Received: 17.03.2021 Accepted: 05.07.2021

\section{ABSTRACT}

Primary cardiac neoplasms are uncommon with an overall incidence of 0.0017 to $0.02 \%$. The majority of these tumors are benign and half of these tumors are myxomas. About $75 \%$ of them are located in the left atrium. Acute embolic cerebral stroke is major problem with increased mortality and morbidity. Embolus arising from cardiac origin costitutes about $20 \%$ of ischemic strokes. Atrial fibrillation is cause of more than $50 \%$ of cardiogenic emboli. Congenital heart diseases, such as atrial septal defect, patent foramen ovale, prosthetic and rheumatic heart valvular disease, dilated cardiomyopathy and endocarditis are predisposing factors for cardiogenic emboli. Emboli from primary tumors of the heart are extremely rare, with an incidence of $0.02 \%$. Myxoma is a potential source of systemic embolization to the brain or peripheral arteries. Thus, cerebral stroke may be the first manifestation of the presence of left atrial myxoma.

Keywords: Myxoma, cerebral embolism, treatment.

\section{ÖZET}

Primer kardiyak tümörler yaygın olmayıp insidansı \% 0.0017 ila 0.02 ’ dir(1). (Bu tümörlerin büyük bir bölümü benign karakterlidir ve bunların da yarısını miksomalar oluşturur. Miksomaların yaklaşık \%75'i sol atriyuma lokalizedir. Akut embolik serebrovasküler olay mortalite ve morbidite artışı ile olan bir sağlık sorunudur. İskemik felçlerin yaklaşık \%20 'si kardiyak kökenlidir. Atriyal fibrilasyon kardiyojenik embolilerin \%50'sinden fazlasını oluşturur. Atriyal septal defekt, patent foramen ovale gibi konjenital kalp hastalıkları, prostetik ve romatizmal kapak hastalıkları, dilate kardiyomiyopati ve endokardit kardiyojenik embolilerde predispozan faktörlerdir. Kalpten kaynaklı primer tümörlere bağlı emboli \%0,002 insidansla oldukça nadirdir. Miksomalar beyin ya da periferik arterler için potansiyel bir sistemik embolizasyon kaynağıdır. Bu nedenle sol atriyal miksomalar ilk bulgu olarak serebrovasküler olay olarak karşımıza çıkabilir.

Anahtar kelimeler: Miksoma, emboli, tedavi.

\section{INTRODUCTION}

Primary cardiac neoplasms are uncommon with an overall incidence of 0.0017 to $0.02 \%$ (1). The majority of these tumors are benign and half of these tumors are myxomas. Acute embolic cerebral stroke is major problem with increased mortality and morbidity. Embolus arising from cardiac origin costitutes about $20 \%$ of ischemic strokes. Atrial fibrillation is cause of more than $50 \%$ of cardiogenic emboli. Congenital heart diseases, such as atrial septal defect, patent foramen ovale, prosthetic and rheumatic heart valvular disease, dilated cardiomyopathy and endocarditis are predisposing factors for cardiogenic emboli (2). Emboli from primary tumors of the heart are 
extremely rare, with an incidence of $0.02 \%$ (3). Myxoma is a potential source of systemic embolization to the brain or peripheral arteries. About $75 \%$ of them are located in the left atrium. Thus, cerebral stroke may be the first manifestation of the presence of left atrial myxoma.

\section{CASE}

A 43-year-old, $60 \mathrm{~kg}$ female patient was admitted to the emergency service with sudden clouding of consciousness and right hemiplegia. She had no known underlying conditions and tachycardia was found in her general examination. Atrial fibrillation was not detected on electrocardiography. On neurological examination, pupillary miotic, light reflex was detected, consciousness was confused, dysarthric speech, Babinski was bilaterally positive. There were signs of right lateralization. The National Institutes of Health Stroke Scale (NIHSS) score was 13, and it was assessed as moderate stroke (5). In consecutive brain computerized tomographies (CT), large hypodense areas in the left frontal, temporal and partially parietal lobes, and infarct areas in the left media cerebri artery irrigation area were noted (Figure 1). It was defined as an ischemic cerebrovascular occurrence according to clinical findings and radiological examinations. When investigating the etiological and predisposing factors, the left ventricular ejection fraction was $60 \%$ normal in all cardiac cavity dimensions, and the mass in the left atrium, moving into the left ventricle and filling the left ventricle in the diastole, was observed on transtorasic echocardiography (TTE) (Figure 2).

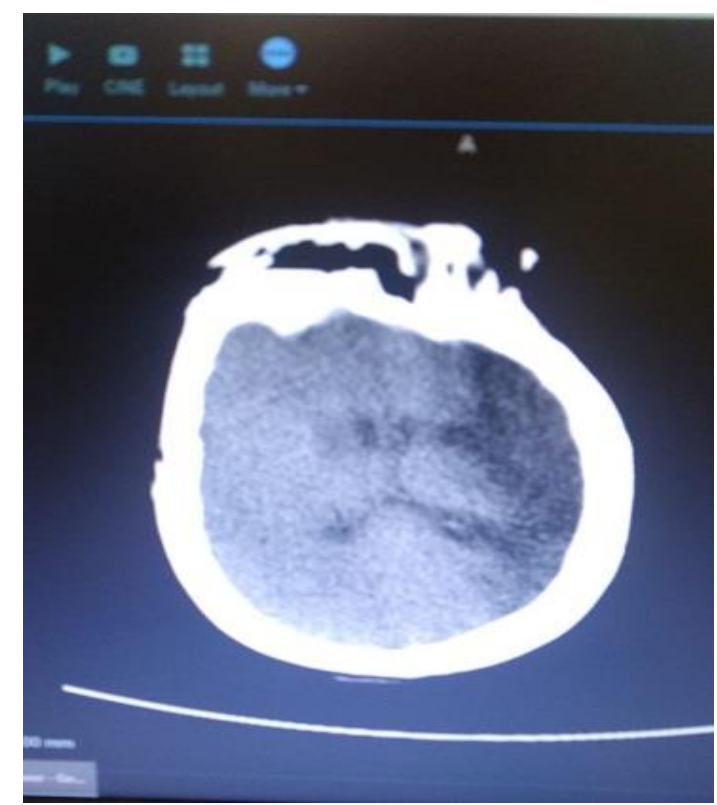

Figure 1: Brain computarized tomographic imagine.

Transesophageal echocardiography (TEE) was performed due to suspicion of myxoma. On TEE, a mobile 76x33 mm hyperechogenic mass extending from the left atrium to the left ventricle and an increase in echogenicity consistent with irregular throm- bus was observed on the mass (Figure 3). Thrombolytic therapy was not recommended to the patient because of the size of the infarct and possible hemorrhagic complications. She was admitted to the cardiovascular surgery intensive care unit for excision of myxoma. Low molecular weight heparin (LMWH) was initiated to prevent recurrent embolism attacks from mobile thrombus. On the 7th day of the follow-up, consciousness and improvement in speech were observed. No hemorrhagic transformation was found in the control brain CT. There was no change in the control TTE at the bedside. On the 12th day, excision of the left atrial myxoma was planned and LMWH treatment was discontinued before surgery. Consent was obtained from the patient for surgery.

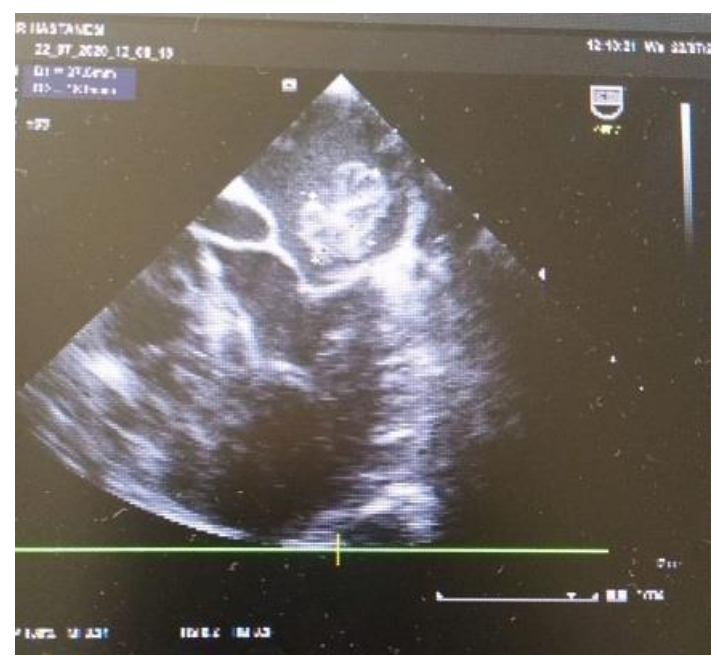

Figure 2: Left atrial mass of transtoracic echocardiographic imagine.

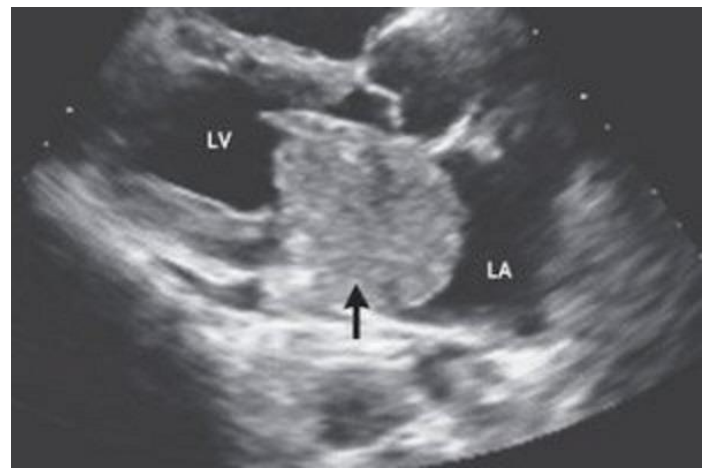

Figure 3: Mass in the left atrium, moving into the left ventricle and filling the left ventricle in the diastole on transesophageal echocardiography.

Invasive monitoring and tracheal intubation was performed. Cardiopulmonary bypass (CPB) was achieved with bicaval cannulation. Left atrial vent was not placed against the possible risk of embolism. It was applied to the total CPB after the cross clamp was placed. Antegrade blood cardioplegia was given by venting from the aortic root. Left atriotomy was performed. The mass protruding from the left atrium 
and filling the left ventricle was delivered and removed. The macroscopic appearance of the mass was $85 \times 45 \times 20 \mathrm{~mm}$ in size, polypoid, irregular, gelatinous and soft (Figure 4). The entire mass was removed. Left ventricular cavity was washed extensively with saline. It was observed that the pedicle of the mass originated from the interatrial septum inferior. Following the excision of the mass, the attachment area of the pedicle was cauterized. After the left atriotomy was closed and air was removed, peroperative TEE was used to control the other heart chambers in terms of air and mass. The aorta is declamped. He left CPB without any problems. Cross clamp time was $22 \mathrm{mi}-$ nutes, CPB time was 56 minutes. The patient was taken to the postoperative cardiovascular surgery intensive care unit. There was no problem with their follow-up. No mass image was found in the control TTE taken 3 months later. Microscopic examination of the pathological report revealed stellate and globular cells, vascular structures, as well as inflammatory hemorrhagic material in the edematous-myxoid stroma, and it was reported as myxoma. The patient was discharged with anticoagulant doses of acetylsalicylic acid, physiotherapy and speech therapy.

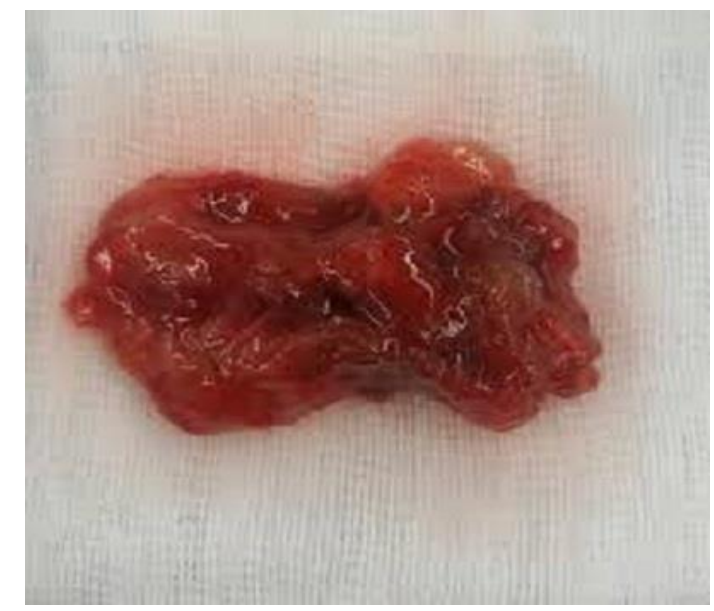

Figure 4: Macroscopic imagine of excised mass.

\section{DISCUSSION}

Acute cerebrovascular events are health problems with increased mortality and morbidity. Approximately $20 \%$ of ischemic strokes are of cardiac origin. Atrial fibrillation accounts for more than $50 \%$ of cardiogenic emboli. Atrial septal defect, congenital heart diseases such as patent foramen ovale, prosthetic and rheumatic valve diseases, dilated cardiomyopathy and endocarditis are predisposing factors in cardiogenic embolism. Embolism caused by primary tumors of the heart is rare and its incidence is $0.02 \%$. The estimated incidence of primary cardiac tumors among randomly selected patients at autopsies is 0.0017 to $0.02 \%$ (5). Most of these tumors are benign and half of them are myxomas. Although most myxomas are classified histologically as benign, thoracic wall invasion may manifest itself in malignant styles such as embolization, heart failure and syncope
(6). In our case, acute cerebrovascular event was the first finding without any predisposing factor.

TTE should be performed to rule out atrial thrombus and / or atrial myxoma, especially in young individuals presenting with cerebral stroke. If the neurological condition allows, the patient whose diagnosis of myxoma is definite should be referred for surgery immediately. However, if the patient's neurological condition is unstable, it is necessary to wait until recovery. At the same time, it should be followed whether there is a hemorrhagic transformation of the cerebral infarction with serial CTs. Thrombolytic therapy in cerebral infarction due to atrial myxoma is controversial (7). In our case, after the patient became conscious and her neurological condition improved, she was taken to surgery, preoperative thrombolytic therapy was not recommended due to the size of the infarction and possible hemorrhagic complications, and she received prophylactic dose of LMWH and conservative treatment.

Approximately $75 \%$ of myxomas are localized to the left atrium. The remainder may be in the right atrium and a small amount in both ventricles. It often originates from the subendocardial mesenchymal cells at the border of the left atrium fossa ovalis. The classic symptom triad includes signs of intracardiac obstruction (pulmonary edema, dyspnoea, orthopnea, syncope, palpitations), embolic signs (central nervous system, peripheral arteries, coronary arteries) and institutional symptoms (fever, weight loss, loss of appetite). Cerebral arteries are affected in more than two-thirds of atrial myxoma cases presenting with systemic embolization (8). Pulmonary arteries, retinal arteries, kidney, spleen, intestines, and lower extremities are other embolization sites (9). Although these embolisms are often from myxomas, they may also be thrombi attached to myxomas (10).

The size of atrial myxomas can vary from $2.7 \mathrm{~cm}$ to $4.8 \mathrm{~cm}$. According to their macroscopic appearance, they are classified into 2 types - type 1 , with irregular or villous surface, gelatinous structure, and type 2, smooth surface and solid structure. Left atrial myxoma excised in our case was evaluated as type 1 . It has been reported that embolism depends on the mobility of the myxoma, not its size (11). Although many cases of giant left atrial myxoma have been reported in the literature, our case is important because its measured dimensions are $85 \times 45 \times 20 \mathrm{~mm}$ and mobile.

The echocardiographic appearance of myxomas changes due to the characteristic features associated with the increased risk of systemic embolization. Ha et al. divided cardiac myxomas into two groups according to their echocardiographic morphology (12). They showed that the risk of systemic embolization was significantly higher in the polypoid type in the study grouped as circular and nonprolapped type and the other as polypoid and prolapped type. In a study by Moriyama et al., postoperative recurrence was found to be the same in both groups 
(13). In a study by Kalçik et al., they stated that the measured dimensions of the tumor, irregular tumor surface and increased left atrial dimensions in TEE are determinant factors for embolic events (14).

Surgical treatment of left atrial myxomas is excision with a median sternotomy with CPB. Although excision has been performed with robotic surgery recently, few cases have been reported due to its usage limitations. . In the study conducted by Kadirogulları et al., 72 patients diagnosed with cardiac mass were analyzed retrospectively. In a study conducted among patients who underwent robotic surgery with median sternotomy, CPB and aortic cross-clamp (ACC) times were found to be significantly longer in robotic surgery (15). Left atrial masses are removed by a right atriotomy approach using transseptal incision or left atriotomy. In tumors with a mass extending to the left ventricle, the mass can be easily removed from the mitral valve orifice by performing left atriotomy. Residual mass control is performed with TEE. In a study by Hatemi et al., Patients who underwent surgery for left atrial myxoma were divided into two groups. Those who underwent left atritomy were group 1, and those who underwent transseptal incision with right atriotomy were divided into group 2. Differences were investigated in terms of cardiac rhythm, left ventricular ejection fraction, pulmonary artery pressures, ACC time, CPB time, postoperative drainage amount, intensive care and hospital stays, and recurrence. ACC time was significantly longer in group 2. We performed left atriotomy and excised the mass from the left ventricle.She was discharged postoperatively without any problem. In the control TTE performed in the 3-month follow-up of the patient, left ventricular ejection fraction was reported as $60 \%$, and no mass was observed in the mitral valve and heart cavities.

Most cardiac myxomas are sporadic and rarely can be a part of familial syndromes. Carney Complex is an autosomal dominant syndrome and may be associated with multiple neoplasms (heart, skin, breast), endocrinopathy, testicular tumors, and schwannoma. Although recurrence is not common in sporadic myxoma, inadequate resection, intraoperative implantation, and embolization of tumor fragments may cause recurrence $(16,17)$.

Our case is a sporadic myxoma and acute cerebrovascular event was admitted to the hospital as the first finding. The left atrial mass should definitely be eliminated by performing TTE in young, female and all patients with stroke, and surgery should be taken immediately after the neurological condition is stable.

\section{REFERENCES}

1. El Bardissi AW, Dearani JA, Daly RC, et al. Analysis of benign ventricular tumors: long-term outcome after resection. J Thorac Cardiovasc Surg 2008;135:1061-1068.
2. Ivanovic BA, Tadic M, Vranes, et al. Cerebral aneurysmassociated with cardiac myxoma: Case report. Bosn J Basic Med Sci 2011,11: 65-68.

3. Vatan MB, Gündüz H, Atakay S, et al. Recurrent embolization of a left atrial myxoma resulting in acute cerebral ischemia. J Clinic Experiment Cardiol 2011;2:159.

4. Reynen K. Frequency of primary tumours of the heart. Am J Cardiol 1996;77:107.

5. Hage V. The NIH stroke scale: a window into neurological status. Nursing Spectrum 2011 (15):44-49.

6. Frank H. Evaluation of congenital heart disease and cardiac masses by magnetic resonance imaging. Journal für Kardiologie 2003;10(1-2):19-25.

7. Lamparter S, Moosdorf R, Maisch B. Giant left atrial mass in an asymptomatic patient. Heart 2004;90:c24.

8. Al Said Y, Al Rached H, Baeesa S, et al. Emergency evcision of cardiac myxoma and endovascular coiling of intracranial aneursym after cerebral infarction. Case Rep Neurol Med 2013;2013: 839270.

9. Pinede D, Pierre D, Loire R.Clinical presentation of left atrial cardiac myxoma: a series of 112 consecutive cases. Medicine (Baltimore) 2001;80.

10. Rescigno G, Matteucci SL, Alfonso D, et al. Acryptogenic pulmonary embolism: Left atrial myxoma showers. Stroke 1993;24:1090-1092.

11. Wold LE. Lie JT. Atrial myxomas occluding an atrial septal defect. J Thorac Cardiovasc Surg 2006;132:1223-1224.

12. Lee VH, Connolly HN, Brown RD. Central nervous system manifestation of cardiac myxoma. Arch Neurol 2007;64:1115-1120.

13. Ha JW, Kang WC, Chung N, et al. Echocardiographic and morphologic characteristics of left atrial myxoma and their relation to systemic embolism. Am J Cardiol 1999;83:1579-1582.

14. Moriyama Y, Saigenji H, Shimokawa S, et al. The surgical treatment of 30 patients with cardiac myxomas: A comparision of clinical features according to morphological classification. Surg Today 1994;24:596-598.

15. Kalçik M, Bayam E, Güner A, et al. Evaluation of the pontial predictors of embolism in patients with left atrial myxoma. Echocardiography 2019;36: 837-843

16. Kadiroğulları E, Onan B, Aydın Ü, et al. A comparasion of robotically-assisted endoscopic versuc sternotomy approach for myxoma excision:A single- center experience. Turk Gogus Kalp Damar Cerrahisi Derg 2020,28(3):450-459.

17. Gerbode F, Kerth WJ. Surgical management of tumors of the heart. Surgery. 1967;61(1):94-101.

18. Pinede L, Duhaut P, Louire R. Clinical presentation of left atrial myxoma. A series of 112 consecutive cases. Medicine. 2001;80(3):159-172. 